\author{
풍하중 산정을 위한 한반도 단독주택의 대표유형 선정 \\ 박종길*·정우식**최효진** \\ *인제대학교 환경공학부/대기환경정보연구센터, \\ **인제대학교 대기환경정보공학과/대기환경정보연구센터 \\ (2009년 10월 26일 접수; 2009년 11월 27일 수정; 2009년 12월 14일 채택)
}

\title{
A Selection of Representative Type the Korean Peninsula Detached Dwelling for Estimate the Wind Load
}

\author{
Jong-Kil Park", Woo-Sik Jung** and Hyo-Jin Choi** \\ *School of Environmental Sciences Engineering, \\ Atmospheric Environment Information Research Center, Inje University, Gimhae 621-749, Korea \\ ${ }^{* *}$ Department of Atmospheric Environment Information Engineering, Graduate school, \\ Atmospheric Environment Information Research Center, Inje University, Gimhae 621-749, Korea \\ (Manuscript received 26 October, 2009; revised 27 November, 2009; accepted 14 December, 2009)
}

\begin{abstract}
As the damages due to natural disasters continue to increase, a growing interest is being witnessed in such studies that focus on preventive measures to reduce damages rather than on their recovery. As such, the U.S. has been actively conducting projects to develop new models that can forecast potential damages due to natural disasters and widely employing them in actual cases. With no specific models developed in Korea yet, this study aimed to introduce an overseas typhoon model as part of the advanced efforts and apply it the actual cases occurring across the nation. This model estimates wind loads by measuring the impact of a strong wind upon buildings, and measurements require a number of parameters. Those parameters should include the types and dimensions of buildings and the type of the roofs. As for the FPHLM(Florida Public Hurricane Loss Model), a precedent model for our study, we were able to take advantage of number of the statistics and detailed categorizations on the residential buildings in the U.S., which enabled us to select the representative building types and produce their wind loads. With no sufficient relevant statistics available for the nation, however, we may not be able to readily measure the wind loads on the nation's residential buildings. Therefore, this study tried to choose the representative types, heights and dimensions of the buildings for the measurement of wind loads. We consequently came up with a representative house having an area between 62.81 and 95.56 $\mathrm{m}^{2}$, either a flat roof or hip roof, a height of $2.6 \mathrm{~m}$, an side ratio of 1.5 , and the width and length of the mean $85 \mathrm{~m}^{2}$ sized house being $11,300 \mathrm{~mm}$ and $7,530 \mathrm{~mm}$, respectively.
\end{abstract}

Key Words : Wind load, Representative type, Detached house

\section{1. 서 론}

2008년 5월은 전 세계에 자연재해의 심각성을 일

Corresponding Author: Woo-Sik Jung, Dept. of Atmospheric Environment Information Engineering, Graduate school, Inje University, Gimhae 621-749, Korea
깨웠다. 5 월 2 일 발생한 미얀마의 사이클론 Nargis 에 의해 총 13 만 3,600 명이 희생되었고, 10 일 미국 중서부를 강타한 토네이도는 최소 18 명 그리고 21

Phone: $+82-55-320-3932$

E-mail: wsjung1@inje.ac.kr 
일 중국 쓰촨성 부근에서 발생한 리히터 규모 7.8 의 강진으로 인해 7 만 2,000 여명이 사망.실종하였다.

IPCC 4차 보고서에 따르면 폭염과 집중호우 등이 계속적으로 빈발할 가능성이 높으며 이와 함께 태 풍과 허리케인 같은 열대성폭풍은 해수면온도 상승 과 더불어 그 위력이 더욱 강화될 것으로 전망하고 있다 ${ }^{1)}$. 실제로 한반도 남해안에 상륙하여 북동쪽 내 륙을 통과하는 유형과 일본 큐슈지방을 통과하여 한반도 남동해안에 영향을 미치는 유형의 태풍이 매년 증가하고 있으며 태풍의 강도 역시 증가하여 많은 피해를 야기하고 있는데, 이와 같은 자연재해 는 발생빈도와 비교하여 그 피해액이 점차 대형화 되고 있다 ${ }^{2,3)}$.

국내에서도 2002년 태풍 Rusa와 Maemi라는 단 하나의 기상현상으로 인해 5 조 1,79 억 원, 4 조 2,301 억 원의 기록적인 피해를 입은 이후, 태풍뿐만 아니 라 전반적인 자연재해를 예방하고자 소방방재청을 신설하고 각 지자체별로 풍수해 저감계획을 구축하 는 등 각고의 노력의 기울여 왔다 ${ }^{4)}$. 구체적으로는 행정구역에 따라 풍수해가 빈번한 여름철을 대비하 여 재해취약시설, 예·경보시설, 방역물자 등 시설 물을 점검하고 민간모니터 요원을 구성, 민간단체 와 지원을 협약하는 등의 재해 피해를 저감하기 위 하여 다방면으로 노력을 기울이고 있다. 그러나 이 와 같은 노력들은 대부분이 정부기관 또는 민간 지 원자 등 특정 대상을 통하여 피해 입은 뒤에 대응 가능한 방법이다. 따라서 효과적인 예방활동을 통 하여 피해를 저감하기 위해서는 태풍의 위험성을 분석할 수 있는 기법을 확립하여 방재유관기관의 신속한 대응을 돕고 다수의 시민들이 피해의 심각 성을 인지하여 예방활동을 할 수 있도록 정보를 제 공해야 한다.

독일의 재보험사 Munich Re를 비롯한 전 세계적 인 보험회사들은 자연재해에 의한 재산피해와 파괴 된 손실을 예보하는 모델을 사용하고 있다. AIR Worldwide Corporation, Risk Management Solutions, ABS Group Company 등에서 여러 가지 자연재해를 대상으로 미국을 포함한 40 여 나라에 대한 정보를 보험사에 제공하고 있다. 이와 같이 보험사를 대상 으로 한 연구는 대부분이 보험 배상금 자료에 근거 하여 취약곡선을 사용하였는데 이 취약곡선은 주택
건물의 종류를 고려하지 못하며, 과거에 피해가 발 생하지 않아 보험금이 지급되지 않은 사례에 대해 서는 적용하기 어렵다는 단점이 있다 ${ }^{5)}$ 현재 미국 Federal Emergency Management Agency(FEMA)에서 는 보험사 모형의 단점을 보완하고 재해위험과 손 실 평가, 대응, 복구까지 모든 과정을 지원 가능한 모형인 HAZUS와 HAZUS-MH (Multi-Hazard)를 개 발·사용하고 있다. 특히 Florida Department of Financial Services(FDFS)에서 지원한 Florida Public Hurricane Loss Model(FPHLM) ${ }^{6}$ 은 허리케인 예보단 계부터 상륙 후 강풍에 의해 각 주택건물의 유형별 로 받는 풍하중을 예측하여 각 요소들의 파괴 확률 및 피해액을 추정할 수 있다. 우리나라도 자연재해 에 의한 피해 규모가 점차 대형화되고 있는데, 특히 태풍의 경우 상륙하기 몇 일전에 진로와 영향 범위, 강도 등이 예보되므로 사전에 철저히 대비한다면 충분히 많은 피해를 저감시킬 수 있다.

태풍이 피해를 입히는 원인은 크게 강우와 강풍 으로 구분할 수 있는데, 특히 태풍 Rusa와 태풍 $\mathrm{Maemi}$ 에 의해 제주도의 월드컵경기장과 부산 아시 아드 주경기장의 지붕막이 파손되기도 하였으며 주 택에도 많은 피해를 주었다. 태풍 Maemi의 경우 피 해가 심했던 부산지역의 해안가에 위치한 고층 아 파트에서 공통적으로 샤시 유리창의 파손이 심하였 고 강풍으로 인해 상당 지역의 아파트 거주자들이 진동에 대한 불쾌감을 느낀 것으로 조사되었닥. 강 풍은 지진과 달리 지표면 위의 대기경계층에 노출 된 부분에 심하게 변동하는 풍속이 시설물에 영향 을 미치고, 그 풍속은 풍압으로 시설물의 표면에 작 용하며, 창유리나 벽을 통하여 보, 기둥에 작용하여 수평력으로 전달된다 ${ }^{8)}$. 강풍에 의한 구조물의 피해 유형은 건축물 및 외장재의 파괴, 지붕의 부양, 송전 시설 파괴, 도로시설물 전도 및 도괴 등을 들 수 있으 며, 특히 지붕이나 치장벽돌, 유리창 등이 건축물로 부터 분리되어 날아가면 인명피해를 일으키는 등에 2차 피해를 유발하여 피해 범위가 넓어질 수 있다 ${ }^{9}$.

우리나라는 3 면이 바다로 둘러싸인 반도 지형이 기 때문에 풍하중이 큰 지역에 속하며 특히 해안 지 역에서는 풍하중에 대한 세심한 고려가 요구되기 때문에 바람의 특성을 올바르게 파악해서 적절한 풍력 및 풍하중을 평가하고 이에 대한 해결책을 세 
워야 한다 ${ }^{10)}$. 따라서 태풍과 같은 강풍현상에 대비 하기 위한 방재대책으로 각 관련법의 정비뿐만 아니 라 단기 및 중장기적인 계획을 수립해야 하며, 태풍 방지용 위험지도-시나리오를 작성하여 사전대응 책을 마련하고 풍해 시에 신속하게 대응할 수 있도 록 중장기적인 풍해 방재대책을 세워나가야 한다 ${ }^{11)}$. FPHLM과 같이 태풍에 의한 강풍이 주택건물 유형 에 따라 주는 풍하중과 피해액을 산정하고 지역별 주 택건물 자료를 토대로 사전에 예상되는 피해규모를 추정한다면 이 것 또한 태풍에 대한 위험지도(Map) 를 구축하는 하나의 방법이 될 수 있다. FPHLM에서 는 주택구조물의 표준화된 분류와 자료를 토대로 주택 유형별로 풍하중을 산정하는데 국내에는 미국 과 같은 주택 분류 자료가 없으므로, 국내 자료를 이용하여 주택건물의 유형을 구분해야 한다.

따라서 본 연구에서는 FPHLM을 국내에 적용하 는 과정에서 풍하중 산정 시 필요한 주택 관련 입력 변수를 정의하기 위하여 한반도의 주택건물을 구분 하고 대푯값이 될 수 있는 보편적인 유형을 선정하 고자 한다.

\section{2. 자료 및 방법}

본 연구에서는 국내 단독주택을 크게 건물 면적, 총 방수, 층수, 지붕 유형, 층고, 폭·길이에 따라 구 분하였다. 유형 분류 과정에서 통계청의 2005년 주 택 총 조사 자료를 ${ }^{12}$ 이용하여 지역별로 단독주택의 호수와 비율, 면적 등을 알아보고 단독주택의 평균 구조와 면적을 선정하였다. 단독주택의 풍하중을 산정하는데 필요한 층고와 지붕 유형, 폭·길이는 건축 관련 법규를 기본으로 선행연구와 건축 전문 가의 조언을 이용하여 보편적인 지붕 유형과 층고 를 선정하였다. 또한 단독주택의 폭과 길이를 정하 는데 사용한 아파트 평면도는 최근 5년간(2003년 2007년) 일반건설업체 시공순위 ${ }^{13)} 5$ 위 내에서 사례 수가 적은 1 개 업체를 제외한 4 개 업체를 선정하여 수치 확인이 가능한 평면도를 이용하였다.

\section{3. 분석 결과}

풍하중을 산정하기 위해서는 건물이 높이, 지붕 의 종류, 지붕의 각도, 외장재, 구조골조 등에 따라
산정식을 다르게 적용한다. 대상 건물의 특성과 일 정한 풍속이 주어지면 풍하중을 산정할 수 있는데 국내 풍하중 기준인 KBC-S 2005(Korean Building Code-Structural) ${ }^{14)}$ 에서는 기본풍속에 평균 10 분 풍 속을 사용하며, 여러 국가들의 풍하중 계산식을 도 입하여 만든 기준이다. 국내 풍하중 기준과 FPHLM 에서 사용하는 풍하중 기준인 ASCE 7-98(미국토목 협회의 건물 하중 국가 표준 기준인 Minimum Design Loads for Buildings and Others Structures code) ${ }^{15)}$ 의 차이점은 기본풍속으로 3-second gust를 사용한다는 점이며 실제 풍동 실험을 기반으로 설계가 되었다 는 장점이 있다. 따라서 본 연구에서는 ASCE 7-98 을 이용하여 풍하중을 산정하는데 필요한 건축물의 주요 요소별 대푯값을 정하고자 한다. ASCE 7-98을 이용하여 풍하중을 산정하기 위해서는 기본적으로 13 개의 입력변수가 필요하다. 이 중에서 건물의 치 수 및 유형과 관련된 변수는 $\mathrm{L}$ (horizontal dimension of a building measured parallel to the wind direction), $\mathrm{B}$ (horizontal dimension of buildings measured normal to wind direction), h(mean roof height of a building), 그리고 건물의 높이와 지붕 유형별로 풍하중 산정 식이 조금씩 다르기 때문에 조건에 맞는 방법을 적 용하기 위하여 지붕 유형이 필요하다. 이와 같은 변 수들에 대한 한반도 주택의 대푯값을 구하고자 다 음과 같은 연구를 수행하였다.

통계청의 주택 총 조사 자료를 이용하여 연도에 따른 주택 종류별 건설 실적과 현재 국내 호수를 알 아본 결과 아파트가 월등히 많은 호수를 보였다 (Fig. 1). 또한 최근에는 아파트도 건축물도 점차 고 층화되어 가고 있으며, 여기에 이상기후로 인한 풍 피해 규모도 점차 커지고 있다. 우리나라 아파트 건 축물들은 대부분 군(群)을 이루고 있어 강풍 시 건 축물의 상호간섭효과로 인하여 복잡한 기류변화가 발생하여 건축물에 예상치 못한 풍압이 증대될 수 도 있다 ${ }^{16}$. 이 등 ${ }^{17)}$ 에 의한 고층건물의 풍동 실험 결 과, 고층건물의 높이에 따른 풍압 분포는 풍상면의 경우 평균적으로 하층부에서는 0.3 , 중층부에서는 0.6 그리고 상층부에서는 0.8 정도를 나타내어, 풍상 면의 평균풍압계수는 높이에 따라 2승 지수적으로 변하는 것으로 분석되었다. 정 ${ }^{18)}$ 역시 초고층 건물 을 대상으로 $\mathrm{CFD}$ 모델을 이용하여 풍속 분포를 해 


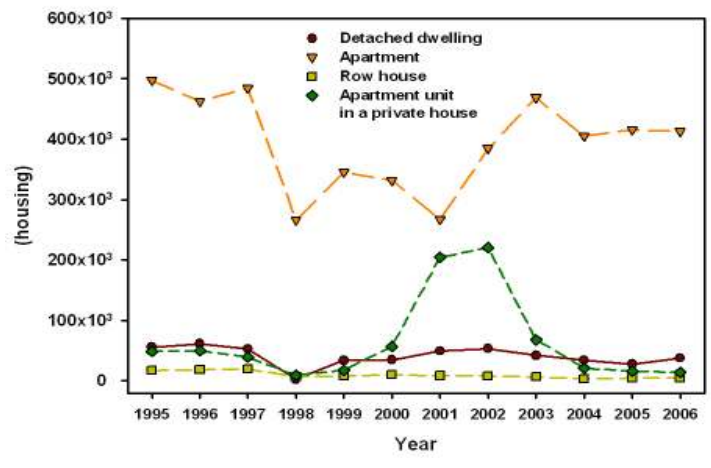

Fig. 1. Housing construction by year.

석한 결과, $3.5 \mathrm{~m}$ 와 $7 \mathrm{~m}$ 높이에서는 빌딩과 주변 건물의 영향을 많이 받고, $10 \mathrm{~m}$ 와 $20 \mathrm{~m}$ 높이에서는 지면 효과에 의한 풍속의 감소가 없고 빌딩의 단면 적도 작기 때문에 빌딩 주변 근처에만 자유류의 교 란이 일어난다고 하였다.

이와 같은 이유로 강풍에 의한 건물의 풍하중 산 정은 저층, 중층, 고층건물과 같이 층별로 이루어져 야 하며, FPHLM의 경우도 연구 대상지역에서 1 층 과 2 층 주택 수가 많음에도 불구하고 1 층 건물을 우 선 대상으로 연구하였다. 고층건물이 많은 아파트 (약 6천 6백만 호)를 제외한 주택 가운데 아파트 다 음으로 호수가 많고 주로 1 2층의 저층으로 이루 어진 단독주택(약 4천만 호)이 본 연구에 적합한 대 상이라 할 수 있다. 따라서 본 연구에서는 이와 같은 단독주택을 대상으로 태풍에 의한 강풍피해를 추정 하기 위한 대표 유형을 선정하였다.

\section{1. 단독주택 평균 구조}

국내에는 본 연구에서 필요한 단독주택의 내·외 장재 종류, 지붕 유형·자재, 주택 높이·폭 등에 대 한 통계자료나 대표적인 형태를 정의하지 않고 있 다. 통계청에서도 주택건물의 구조 유형별로 구분 한 자료는 제공되지 않으며 향후 건축물 대장 정비 사업이 완료되는 2010 년에는 이와 같은 통계 자료 에 대한 적정성을 검토 가능할 것이다. 따라서 통계 청의 주택 총 조사 자료와 선행연구를 이용하여 국 내 단독주택의 대표적인 형태를 정의하였다.

Fig. 2와 같이 '광역시'와 '도' 단위별 주택 유형 분포를 보면 전체 주택 호수는 경기도와 서울이 가 장 많으며 다른 지역과도 월등히 많은 차이를 보인

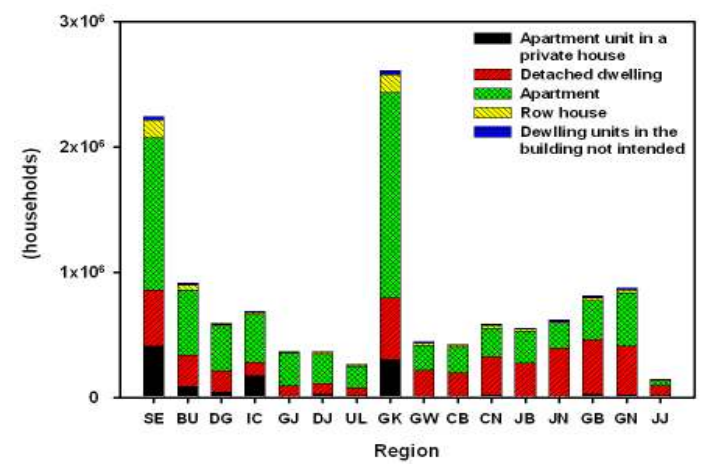

Fig. 2. Type of housing by region(2005).

다. Fig. 1 에서와 같이 전 지역에 걸쳐 아파트가 가 장 많은 호수를 차지하고 지역에 따라 주택건물의 분포가 크게 다른 것으로 보아 같은 태풍이 내습하 더라도 주택에 대한 피해 규모의 차이가 크기 때문 에 지역의 특성을 고려하고 충분한 통계자료를 기 반으로 한다면 더 정확한 방재정보를 제공할 수 있다.

통계청에서는 주택을 크게 '단독주택(Detached dwelling), 아파트(Apartment), 연립주택(Row house), 다세대주택(Apartment unit in a private house), 영업 용건물내주택(Dwelling unit in the building not intended)' 으로 구분하고 있는데, 본 연구에서 대상으 로 하는 단독주택은 지역에 따라 다르지만 전체 주 택 가운데 약 $23 \sim 60 \%$ 의 비율을 보인다. 전국적으 로 약 $40 \%$ 정도 되며 광역시 단위에서는 특히 인천 과 경기가 $30 \%$ 이하의 낮은 비율을 보이며 서울과 부산은 전국과 비슷한 비율을 가진다. 광역시보다 '도' 단위에서 단독주택의 비율이 $50 \%$ 정도로 높게 나타나고 있지만 경기도는 전국에서 가장 많은 주 택 호수를 가지면서도 단독주택의 비율이 $29.5 \%$ 로 나타나서 인천 다음으로 낮은 비율을 나타내었다.

단독주택은 다시 '일반단독주택(Ordinary detached dwelling), 다가구단독주택(Multi- family house), 영 업겸용단독주택(A combination of dwelling and business)' 으로 구분할 수 있는데, 본 연구에서 대상으 로 하는 일반단독주택에 대해서 Fig. 4와 같이 지역 별 면적분포를 알아보았다. Fig. 2의 전체 주택건물 의 분포와 비교하여 '광역시' 단위와 '도' 단위의 단 독주택 호수 차이가 많이 줄었음을 알 수 있다. 이는 수도권인 경기도에 아파트가 집중되어 있으며 상대 적으로 주택호수가 적은 강원도 전라도, 경상도 지 


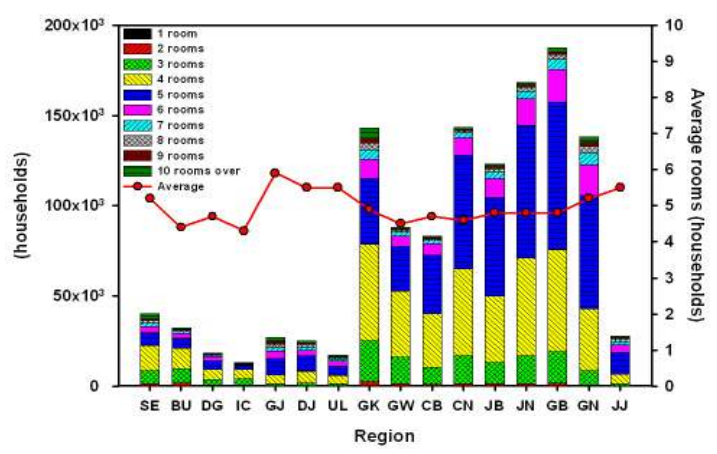

Fig. 3. Detached dwelling total rooms by region(2005).

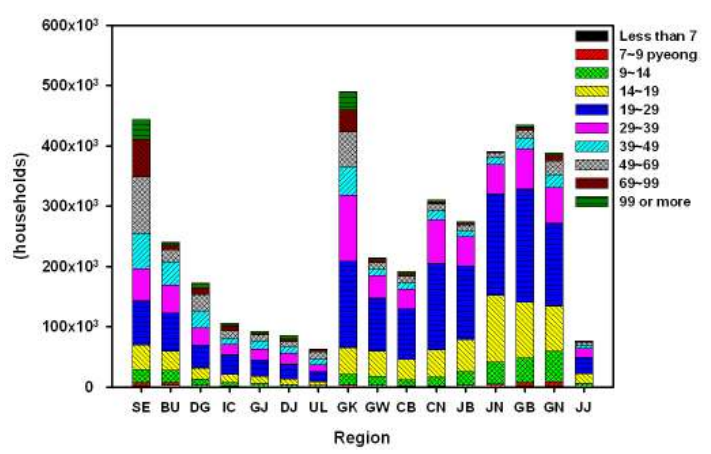

Fig. 4. Total area of ordinary detached dwelling by region(2005).
역에 저층인 단독주택이 많이 분포함을 나타내는 것이다.

전국을 비롯하여 16 개 시도의 일반단독주택 가운 데 연건평이 $19 \sim 29$ 평인 호수가 약 $42 \%$ 의 비율을 보여 19 29평이 가장 대표 면적이라 할 수 있다. 그리고 주택의 방수에 따라서 창문의 개수가 달라 지는데 창문 수에 따라 강풍에 의해 파손될 수 있는 피해액이 달라지므로 방의 수를 정하는 과정도 중 요하다. 따라서 Fig. 3과 같이 대표 면적에 해당되는 일반단독주택에서의 방수를 보면 지역별로 4 5개 에 해당하는 방수가 보편적이나 평균값으로 보면 방 5 개인 경우가 가장 대표적이다.

통계청의 2005년 주택 총 조사 자료를 이용하여 대표 주택 면적을 알아본 결과, 단독주택에서 가장 많은 호수를 차지하는 면적은 62.81 95.56 m²(19 29 평)으로 1 가구가 거주하며 총 5 개의 방(평균적으 로 침실 3 개)을 가진다. 이와 같이 주택 총 조사 자 료에서 단독주택의 평균 면적이 62.81 95.56 $\mathrm{m}^{2}$ (19 29평) 범위를 가지나, 뒤에 평면도 조사에서도 언 급되는바와 같이 국민주택규모 기준이 $85 \mathrm{~m}^{2}(25.7$ 평) 이하 이다. 따라서 평균 면적 범위 내에서 사실 은 $85 \mathrm{~m}^{2}$ 이하의 단독주택이 많이 건설되므로, 국내

Table 1. Ordinary detached dwelling research data(2005)

\begin{tabular}{c|r|r|r|r|r|r|r}
\hline \multirow{2}{*}{ Region } & \multicolumn{2}{|c|}{ (Households) } & \multicolumn{2}{|c|}{ Total area } & Total rooms \\
\cline { 2 - 8 } & $\begin{array}{c}\text { Ordinary detached } \\
\text { dwelling }\end{array}$ & Total & $(\%)$ & $\begin{array}{r}19 \sim 29 \\
\text { pyeong }\end{array}$ & Total households & $(\%)$ & average \\
\hline \hline Korea & $17,993,358$ & $45,452,526$ & 39.6 & $1,260,621$ & $3,013,905$ & 41.8 & 5.0 \\
SE & $3,625,439$ & $9,449,004$ & 38.4 & 52,849 & 196,275 & 26.9 & 6.7 \\
BU & $1,334,562$ & $3,408,163$ & 39.2 & 62,804 & 129,546 & 48.5 & 5.8 \\
DG & $1,035,471$ & $2,399,322$ & 43.2 & 38,316 & 79,102 & 48.4 & 5.9 \\
IC & 578,461 & $2,453,438$ & 23.6 & 33,325 & 73,760 & 45.2 & 5.1 \\
GJ & 473,824 & $1,367,577$ & 34.6 & 26,870 & 55,017 & 48.8 & 5.9 \\
DJ & 494,829 & $1,394,783$ & 35.5 & 21,261 & 53,975 & 39.4 & 5.5 \\
UK & 357,594 & $1,015,165$ & 35.2 & 14,230 & 34,964 & 40.7 & 5.5 \\
GK & $2,943,326$ & $9,977,525$ & 29.5 & 127,629 & 327,160 & 39.0 & 4.9 \\
GW & 710,144 & $1,402,191$ & 50.6 & 84,934 & 191,678 & 44.3 & 4.5 \\
CB & 579,127 & $1,399,722$ & 41.4 & 80,537 & 167,398 & 48.1 & 4.7 \\
CN & 946,282 & $1,790,709$ & 52.8 & 140,860 & 294,148 & 47.9 & 4.6 \\
JB & 837,998 & $1,716,780$ & 48.8 & 119,632 & 256,349 & 46.7 & 4.8 \\
JN & $1,034,478$ & $1,749,454$ & 59.1 & 163,954 & 373,493 & 43.9 & 4.8 \\
GB & $1,284,008$ & $2,477,481$ & 51.8 & 180,106 & 396,343 & 45.4 & 4.8 \\
GN & $1,361,112$ & $2,937,244$ & 46.3 & 127,189 & 321,679 & 39.5 & 5.2 \\
JJ & 299,703 & 513,968 & 58.3 & 25,592 & 63,018 & 40.6 & 5.5 \\
\hline
\end{tabular}


단독주택의 평균 면적을 $85 \mathrm{~m}^{2}$ 이라 할 수 있다.

\section{2. 단독주택 지붕 유형}

국내의 지붕구조 유형은 여러 가지 종류가 많이 있고 특별한 유형과 정형화된 유형을 찾아내기는 힘들므로 ${ }^{19)}$, 단독주택의 지붕 유형에 대한 통계자료 와 선행연구를 토대로 정의할 수 있다. 정 ${ }^{19)}$ 의 경우 단독주택에서 나타날 수 있는 14 가지 지붕 유형을 제시하였는데 외쪽지붕, 박공지붕, 모임지붕, 반박 공지붕, 합각지붕, 꺾인지붕, 망사르드지붕, 볼트, 스노덕트지붕, 방형지붕, $\mathrm{HP}$ 셀, 돔, $\mathrm{M}$ 자형지붕, 톱 날지붕 중에서 박공지붕과 모임지붕을 가장 기본적 인 유형이라 하였다. 오 ${ }^{20)}$ 역시 단독주택에서 쓰이 는 16 가지 지붕을 제시하였는데 외쪽지붕, 박공지 붕, 모임지붕, 합각지붕, 방형지붕, 눈썹지붕, 반박 공지붕, 맨사드지붕, 평지붕, 솟을지붕, 꺾인지붕, 톱날지붕, 반원지붕, 뾰족지붕, 원추지붕, 돔이 있 다. 남과 이 ${ }^{21)}$ 는 1 층 단독주택에 대하여 풍하중 해 설 및 설계 ${ }^{22)}$ 에서 제시하는 평지붕, 곡면지붕, 편지 붕, 박공지붕, 다중박공지붕, 톱니지붕과 같이 6 가 지로 구분하였는데, 이 6가지 지붕 유형은 국내 저 층건물의 일반적인 유형에 해당되므로 대표 유형이
라 할 수 있다.

그러나 FPHLM의 ${ }^{6)}$ 경우에도 여러 가지 지붕 유 형 가운데 상대적으로 많이 사용되는 Gable Roof와 Hip Roof 2 가지를 선정하여 차후 주택의 유형을 구 분하는데 사용하였다(Table 2). 따라서 본 연구에서 도 국내 저층건물의 일반적인 지붕 형상 6 가지를 다 고려할 수는 없으므로 이 중에서도 대표 유형을 선 정해야 할 필요가 있다.

신 $^{23)}$ 은 충주시와 제천시, 원주시의 185 개 단독주 택을 대상으로 건축허가도면과 건축물관리대장, 그 리고 현장 관찰을 통하여 주택을 조사한 결과, Table 3 과 같이 연대별 지붕 형태 자료를 분류하였다. 평 지붕과 눈썹지붕, 모임지붕 순서로 많은 분포를 보 이는데 눈썹지붕은 본질적으로는 평지붕형식이므 로 $^{23)}$, 풍하중 해설 및 설계에서 제시한 6 가지 지붕 유형 중 평지붕(Flat Roof)과 모임지붕(Hip Roof)이 가장 대표적인 유형이라 할 수 있다(Fig. 5).

\section{3. 단독주택 층고}

단독주택의 풍하중을 계산하기 위해서는 건물의 높이, 폭·길이에 대한 정보가 있어야 된다. 건물의 높이로 천정고는 바닥 마감된 윗면과 마감된 천정

Table 2. Assumed structural type definitions ${ }^{16)}$

\begin{tabular}{|c|c|c|c|c|}
\hline & No of Stories & Exterior Wall & Roof Materials & Roof Type \\
\hline Type 1 & 1 story & concrete blocks & Shingle/Tile & Gable \\
\hline Type 2 & 1 story & concrete blocks & Shingle/Tile & Hip \\
\hline Type 3 & 1 story & Wood & Shingle/Tile & Gable \\
\hline Type 4 & 1 story & Wood & Shingle/Tile & Hip \\
\hline Type 5 & 2 story & $\begin{array}{l}1 \text { story : concrete blocks; } \\
2 \text { story : wood }\end{array}$ & Shingle/Tile & Gable \\
\hline Type 6 & 2 story & $\begin{array}{l}1 \text { story : concrete blocks; } \\
2 \text { story : wood }\end{array}$ & Shingle/Tile & Hip \\
\hline Type 7 & 2 story & Wood & Shingle/Tile & Gable \\
\hline Type 8 & 2 story & Wood & Shingle/Tile & Hip \\
\hline Type 9 & 1 story & concrete blocks & Metal & Gable \\
\hline Type 10 & 1 story & concrete blocks & Metal & Hip \\
\hline Type 11 & 1 story & Wood & Metal & Gable \\
\hline Type 12 & 1 story & Wood & Metal & Hip \\
\hline Type 13 & 2 story & $\begin{array}{l}1 \text { story : concrete blocks; } \\
2 \text { story : wood }\end{array}$ & Metal & Gable \\
\hline Type 14 & 2 story & $\begin{array}{l}1 \text { story : concrete blocks; } \\
2 \text { story : wood }\end{array}$ & Metal & Hip \\
\hline Type 15 & 2 story & Wood & Metal & Gable \\
\hline Type 16 & 2 story & Wood & Metal & Hip \\
\hline
\end{tabular}


Table 3. The distribution of detach dwelling roof types by year(\%)

\begin{tabular}{|c|c|c|c|c|c|c|c|c|}
\hline Types & $60 \mathrm{~s}$ & $\begin{array}{l}\text { the first } \\
\text { half } 70 \mathrm{~s}\end{array}$ & $\begin{array}{l}\text { late in } \\
\text { the } 70 \mathrm{~s}\end{array}$ & $\begin{array}{l}\text { the first } \\
\text { half } 80 \mathrm{~s}\end{array}$ & $\begin{array}{l}\text { late in } \\
\text { the } 80 \mathrm{~s}\end{array}$ & $\begin{array}{l}\text { the first } \\
\text { half } 90 \mathrm{~s} \\
\end{array}$ & $\begin{array}{l}\text { late in } \\
\text { the } 90 \mathrm{~s}\end{array}$ & Average \\
\hline Flat & 23.1 & 39.0 & 46.3 & 41.6 & 50.0 & 66.7 & 58.1 & 52.8 \\
\hline Eyeblow & 0.0 & 0.0 & 0.0 & 5.3 & 34.2 & 21.6 & 29.0 & 18.9 \\
\hline Gable & 15.4 & 17.2 & 33.3 & 15.8 & 7.9 & 3.9 & 3.2 & 8.9 \\
\hline Hip & 53.8 & 43.8 & 20.3 & 37.3 & 5.3 & 2.0 & 3.2 & 15.6 \\
\hline Other & 7.7 & 0.0 & 0.0 & 0.0 & 2.6 & 5.9 & 6.5 & 3.9 \\
\hline
\end{tabular}

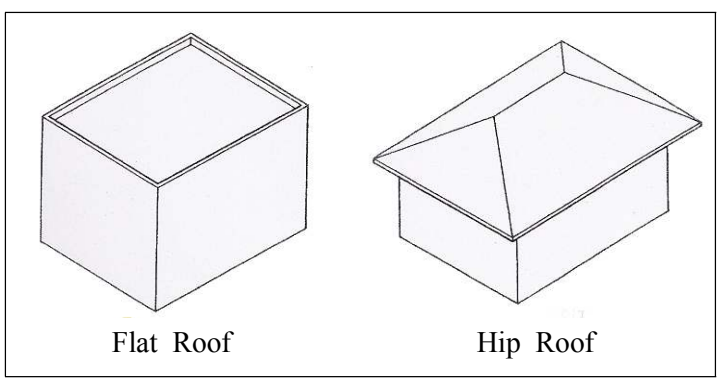

Fig. 5. Representative roof types of ordinary detached dwelling.

면간의 수직 거리이며, 층고는 두 개의 평해한 바닥 면간의 수직거리를 말한다. 이 치수들은 절대적인 기준은 정해져 있지는 않으나 보편적인 치수를 권 장하고 있다. 이 ${ }^{24)}$ 는 단독주택의 거실 천정고가 2.1 $\mathrm{m}$ 이상은 되어야 하며, 오 ${ }^{20)}$ 는 각종 주택재료나 구 법에 의해 구성되는 주택 내의 각 부위 치수 및 공 간 치수를 주택부품생산의 기준 치수로서 공동 명 칭으로 부르며 일정한 치수를 설정하고 있는데 일 반적으로 서양식 건물의 천정고는 $2.4 \sim 3.2 \mathrm{~m}$, 층고 는 2.6 3.0 m 라고 하였다. 또한 최 ${ }^{25)}$ 도 일반적으 로 방의 천정고는 $2.4 \sim 2.4 \mathrm{~m}$ 이며 1 층 바닥의 높이 는 $0.5 \mathrm{~m}$ 이상이라 하였다. 따라서 국내 단독주택의 보편적인 천정고는 $2.3 \sim 2.6 \mathrm{~m}$, 층고는 $2.6 \sim 3.0 \mathrm{~m}$ 범위라 할 수 있다.

그러나 층고도 면적과 같이 치수 범위 내에서도 가장 대푯값을 선정해야 한다. 주택건설기준등에관 한규칙 제 3 조 ${ }^{26)}$ 에 의하면 층높이는 $2.4 \mathrm{~m}$ 이상으로 하게 되어 있으며 건축설계법규 상에서의 층고와 용적률 등에 대한 제한과 경제적인 면을 고려하여 국내에서 기존의 공동주택 층고는 주로 $2.6 \mathrm{~m}$, 천정 고는 $2.3 \mathrm{~m}$ 로 공용화되어 있다 ${ }^{27)}$. 2005년에 소방법 개정으로 11 층 이상의 일반아파트를 비롯하여 스프 링클러를 설치할 수 있도록 층간간격이 $150 \mathrm{~mm}$ 로
의무화되었으며 최근에 건설되는 고급아파트들의 층고가 점차 높아지고 있어, 주택공사벽식아파트의 표준 층고 또한 $2.7 \mathrm{~m}$ 이다 ${ }^{28)}$. 그러나 기존에 지어진 층고가 $2.6 \mathrm{~m}$ 에 해당되는 건물들이 더 많으며, 특히 본 연구의 대상인 1 층 단독주택은 스프링클러를 의 무적으로 설치해야 하는 경우에 해당되지 않으므 로, 국내 단독주택의 평균 층고는 $2.6 \mathrm{~m}$ 로 정의할 수 있다.

\section{4. 단독주택 변장비}

변장비(side ratio)는 건물의 장변과 단변의 비를 나타낸 값으로 풍하중을 계산하기 위해서는 Table 4와 같이 건물의 폭.너비도 필요하다. 그러나 앞서 기술하였듯이 주택에 대한 통계자료가 제대로 구축 되어 있지 않은 상황에서 변장비에 대한 정보를 얻 기는 어렵다. 또한 건물 높이와는 달리 권장하는 치 수가 없으며 주택의 설계 면적과 토지 면적 등에 따 라 충분히 변할 수 있는 수치이므로, 국내 단독주택 의 평균 면적에 대한 보편적인 변장비를 가정할 필 요가 있다. 그러나 지금까지 단독주택에 대한 연구 들은 대부분이 공간구조변화에 대한 내용이 대부분 으로, 본 연구에서 필요한 62.81 95.56 $\mathrm{m}^{2}(19 \sim 29$ 평) 면적에 해당되는 단독주택의 크기에 대한 대표 치수는 국내에서 구할 수 없었다. 따라서 앞서 3.2에 서 선정한 단독주택의 대표면적과 변장비를 구한다 면 주택의 폭과 너비를 도출할 수 있다. 대표 면적에 해당하는 단독주택의 평면도를 이용하여 보편적인 변장비를 얻고자 한다.

Table 4. Manufactured home dimensions ${ }^{6}$

\begin{tabular}{cccc}
\hline Structural Type & Length $(\mathrm{ft})$ & Width $(\mathrm{ft})$ & a $(\mathrm{ft})$ \\
\hline \hline MH 1 & 56 & 13 & 3 \\
MH 2 & 56 & 26 & 3 \\
MH-pre & 56 & 13 & 3 \\
\hline
\end{tabular}


단독주택의 공간구조에 관한 선행연구도 평면도 를 이용하였다. 손 ${ }^{29)}$ 은 1970 년대 이후 계획된 작품 주택 가운데 국내 건축전문지에 2 회 이상 게재된 사 례를 대상으로 하였으며, 이 ${ }^{30)}$ 는 서울 평창동과 일 산도시설계지구에서 1995 2000년에 건축된 단독 주택의 평면유형 및 공간조사, 설계도면 기초자료 조사와 설계도면을 통한 조사 대상지역의 각 건물 을 현장 답사하였다. 또한 임 ${ }^{31)}$ 은 $1964 \sim 1985$ 년까 지 서울시내 17 개 구청에서 각 해당연도에 허가된 허가도면 가운데 당해 연도에 볼 수 있는 보편적 형 식의 건물을 선택하여 총 511 개의 단독주택을 대상 으로 연구하였다.

본 연구에서도 선행연구와 같이 특정 지역 내의 단독주택에 대한 설계도면 또는 현장 답사를 통하 여 단독주택의 정확한 치수를 찾을 수도 있으나, 정 확한 치수 보다는 평균 면적에 해당되는 단독주택 의 보편적인 변장비를 찾아내는 것이 중요하다. 따 라서 단독주택과 전체적인 내부구조 및 평면도가 크게 다르지 않으며 상대적으로 자료가 많고 접근 성이 좋은 아파트 평면도를 이용하여 단독주택의 변장비를 정의하고자 한다.

아파트의 면적은 크게 전용면적, 공급면적, 주거 공용면적, 기타공용면적, 계약면적으로 구분할 수 있는데 전용면적이 주택 내부에서 실제적으로 이용 가능한 면적이라 할 수 있으며, 단독주택이 경우 전 용면적과 공용면적의 구분이 없으므로, 단독주택의 전체 면적과 아파트의 전용면적이 같다고 할 수 있 다 ${ }^{32)}$.

아파트 평면도 조사에 앞서 업체를 선정해야 하 므로 대한건설협회 ${ }^{13}$ 에서 발표한 일반건설업체 시 공순위 가운데 2003 2007년 기간 동안 1 5위 내 에 있는 5 개 업체를 선정하였다. 이 중에서 현대건 설(아이파크)은 단독주택 평균 면적에 해당되는 사 례가 적어 제외하였으므로, 총 4 개 업체인 대우건설 $(\text { 푸르지오 })^{33)}$, 대림산업 $(\mathrm{e} \text {-편한세상 })^{34)}$, 지에스건설 $\left({ }^{(} \text {자이 }\right)^{35)}$, 삼성물산(래미안) $)^{36)}$ 을 대상으로 하였다. 대상 사례는 아파트의 전용면적이 단독주택의 평균 면적 62.81 95.56 $\mathrm{m}^{2}$ 에 해당되는 경우로 정확한 수 치 확인이 가능한 평면도를 대상으로 하였다. 본 연 구에서 이용한 아파트 평면도는 총 110 개 사례로 입 주예정일이 2008년 6월 2010년 12월에 해당된다.
Table 5. Side ratio of apartment total area $62.81 \sim 95.56 \mathrm{~m}^{2}$

\begin{tabular}{cccc}
\hline Total area & Case & Mean area & Side ratio \\
\hline \hline 29 & 1 & 77.03 & 1.5 \\
30 & 2 & 76.84 & 1.4 \\
31 & 1 & 75.52 & 1.3 \\
32 & 17 & 84.85 & 1.5 \\
33 & 47 & 86.61 & 1.5 \\
34 & 25 & 84.92 & 1.6 \\
35 & 17 & 84.95 & 1.6 \\
\hline Total & 110 & 81.53 & 1.5 \\
\hline
\end{tabular}

110 개 사례에 대하여 면적별로 변장비를 계산한 결 과는 Table 5와 같으며 평수는 아파트의 공급면적이 며 평균면적이 전용면적에 해당된다. 이 결과를 바 탕으로 평균 면적 범위 내에 들어가는 주택의 보편 적인 변장비는 1.5 라 할 수 있다. 선정된 비율과 앞 에서 정의한 평균 면적 $85 \mathrm{~m}^{2}$ 에 대하여 대표적인 수 치를 구하면 폭·길이는 $11,300 \mathrm{~mm}$ 와 $7,530 \mathrm{~mm}$ 라 할 수 있다.

\section{4. 결 론}

본 연구에서는 태풍에 의한 주택의 강풍 피해를 산정하기 위한 기초 연구로써 통계청의 주택 총 조 사 자료를 이용하여 한반도 1 층 단독주택의 보편적 인 유형을 정의하였다. 일반단독주택은 전국적으로 약 $42 \%$ 정도 차지하고 있으며 '광역시' 단위보다 '도' 단위에서 더 많은 비율을 보였다. 일반단독주 택은 62.81 95.56 $\mathrm{m}^{2}$ (19평 29평)으로 1가구가 거 주하며 총 5 개의 방(평균 침실 3 개)을 가진다. 그러 나 국민주택규모 기준이 $85 \mathrm{~m}^{2}$ (25.7평) 이하로 해당 면적에서는 주로 $85 \mathrm{~m}^{2}$ 를 넘지 않으므로 우리나라 1 층 일반단독주택의 평균 면적은 $85 \mathrm{~m}^{2}$ 로 정하였다.

단독주택의 지붕 유형은 많이는 16 가지로 구분이 되지만 풍하중 해설 및 설계 ${ }^{22}$ 에서 제시하는 국내 저층건물의 일반적인 지붕 유형 6 가지 중에서 국내 185 개 단독주택을 대상으로 지붕 형태를 조사한 선 행연구를 이용하여 대표 지붕 유형을 평지붕과 모 임지붕으로 정의하였다. 단독주택의 층고는 아파트 와 서양식 건물의 층고에 대한 선행연구와 문헌조 사를 통하여 층고는 $2.6 \mathrm{~m}$ 로 정의하였다.

태풍에 의한 건물의 강풍 피해를 산정하기 위해 
서는 건물에 대한 풍하중을 산정해야 하는데 이 때 필요한 요소 중에 변장비도 포함 된다. 본 연구에서 는 대한건설협회에서 발표한 일반건설업체 시공순 위 가운데 2003년 2007년 기간 동안 1 5위 내에 있는 4개 업체를 대상으로 아파트 전용면적이 단독 주택의 평균 면적 범위인 $62.81 \sim 95.56 \mathrm{~m}^{2}$ 에 해당되 는 평면도를 이용하여 단독주택의 변장비를 정의하 였다. 총 110 개의 평면도를 이용하여 면적당 변장비 를 구한 결과 보편적인 값이 1.5 로 나왔으므로 이 변장비를 이용해서 일반단독주택의 대표 면적인 85 $\mathrm{m}^{2}$ 에 대해서 폭길이를 구한 결과 $11,300 \mathrm{~mm}$ 와 $7,530 \mathrm{~mm}$ 로 정의하였다.

현재 한반도에 태풍이 내습할 경우 지상의 주택 에 미칠 수 있는 강풍 피해를 추정하는 재해예측모 형을 구축하는 과정에 있으며, 차후에 재해예측모 형을 이용하여 재해가 예상될 때 신속한 정보를 전 달하여 사전예방활동에 적극 활용함으로서 인명피 해와 재산피해를 최소화할 수 있다. 본 연구에서는 한반도 대표 단독주택 유형을 선정하였으나 주택 면적, 지붕 유형, 층 수 등 다양한 계속적인 연구를 통하여 다른 주택 유형에 대해서도 적용가능하다. 그리고 국내에도 FPHLM과 같이 구체적인 건물 유 형 분류 자료가 빠른 시일 내에 구축되어야 더 정확 한 재해예측모형을 구축할 수 있을 것이다.

\section{감사의 글}

이 연구는 기상청 기상지진기술개발사업(CATER 2006-3303)의 지원으로 수행되었습니다.

\section{참 고 문 헌}

1) 기상청, 2008, 기후변화 2007-과학적 근거.

2) 박종길, 김병수, 정우식, 김은별, 이대근, 2006, 한 반도에 영향을 주는 태풍의 통계적 특성 변화, Atmosphere, 16(1), 1-17.

3) 박종길, 정우식, 최효진, 2008 , 자연재해저감을 위 한 한반도 피해 취약성 분석 : 공공시설피해를 중 심으로, 한국환경과학회지, 17(4), 83-93.

4) 최효진, 2007, 자연재해저감을 위한 방재기상정보 활용과 재해평가 모형 검토, 석사학위논문, 대기환 경정보공학과, 인제대학교, 김해.

5) 국립방재연구소, 2006, 태풍위험도 추정을 위한 알 고리즘 분석 연구.
6) Florida Department of Financial Services, 2005, Florida Public Hurricane Loss Projection Model, Engineering Team Final Report Volume I -III.

7) 강현진, 김남영, 윤성원, 2003 , 태풍 매미의 강풍에 의한 부산지역의 피해사례, 대한건축학회 학술발 표회 논문-계획계/구조계, 23(2), 281-284.

8) 김종락, 2004, 우리나라 태풍의 피해와 내풍설계에 대한 제안, 대한건축학회, 건축, 4(7), 21-27.

9) 김종락, 이광열, 김영덕, 하영철, 이철재, 2003 , 2002년 9호(펑센)과 15호(루사) 태풍에 의한 제주 도의 풍피해, 한국풍공학회, $6,22-27$.

10 ) 선우원일, 양승배, 정광양, 2004 , 초고층 건축물에 서 바람의 영향, 대한건축학회, 건축 4(7), 35-39.

11) 이혜연, 최창식, 2004, 태풍의 피해 분석을 통한 풍 해 방재대책 개선에 관한 연구, 한국구조물진단학 회 학술발표회논문집, 8(2), 255-260.

12) http://www.kosis.kr/.

13) 대한건설협회, 2003-2007, 일반건설업체 시공순위.

14) 건설교통부, 2005, Korean Building Code-Structural (KBC-S).

15) American Society of Civil Engineering(ASCE), 1998, Minimum Design Loads for Buildings and Other Structures(ASCE 7-98) code.

16) Cho K. P., S. G. Hong, Y. K. Tamura and A. K. Yoshida, September, 2005, Typhoon (Maemi) Attack and its Damage in Southern Korea Celebrating Thanksgiving Festival of Chusok, Sixth Asia-Pacific Conference on Wind Engineering, Seoul, Korea.

17 ) 이은지, 황성권, 김동우, 하영철, 2008 , 고층건축물 의 풍상면 및 풍하면 평균풍압의 연직분포 특성, 대한건축학회 논문집-구조계, 24(3), 35-42.

18) 정영배, 2003 , 초고층 건물 주변의 풍환경 예측을 위한 수치 시뮬레이션에 관한 연구, 한국주거환경 학회, 주거환경(논문집), 제 1권 창간호, 183-190.

19) 정용복, 2006, 주택지붕 형상에 따른 태양광발전 모 듈의 음영영향 평가연구, 석사학위논문, 건축공학 화, 한밭대학교, 충남.

20) 오영근, 1998 , 인체척도에 의한 실내공간계획, 도서 출판국제.

21) 남광현, 이승수, 2003 , 웹기반 건축물 풍하중 산정 프로그램의 개발, 한국풍공학회 학술발표대회논문 집, 6(5), 9-15.

22) 대한건축학회, 2001, 풍하중 해설 및 설계.

23) 신동규, 2002 , 건축적 적응행위에 의한 주거공간 변 형에 관한 연구, 박사학위논문, 건축학과, 성균관대 학교, 수원.

24) 이종석, 2006 , 건축기사 대비 건축계획 I, 한솔아카 데미.

25 ) 최재순, 2000 , 주거공간의 계획과 설계, 기문당.

26) 주택건설기준등에관한 규칙 제 3 조(치수 및 기준척도).

27) 이상엽, 2008 , 기존공동주택의 설비성능의 문제점 및 개선방안, 한국리모델링협회지 Remodeling, 26, 
$52-55$.

28) 한상국, 홍현진, 양우현, 2007, 대규모 집합주택 단 지의 소규모 블록화 가능성 검토와 블록형 집합주 택 모델 제안, 한국도시설계학회지 도시설계, 8(3), 5-20.

29) 손세관, 1998 , 평면의 형상으로 바라본 우리나라 단 독주택의 공간 구성적 특성에 관한 연구, 대한건축 학회논문집, 14(3), 35-42.

30) 이현병, 2001, 도심지 단독주택의 평면유형 및 특성 에 곤한 조사연구, 부천대학 논문집, 22, 13-20.
31) 임창복, 1989 , 한국 도시 단독주택의 유형적 지속성 과 변용성에 관한 연구, 박사학위논문, 건축학과, 서울대학교, 서울.

32) 건설교통부령 주택건설촉진법 시행규칙 제 17 조 제 2항(2003. 12. 15).

33) http://www.prugio.com/.

34) http://www.dalim-apt.co.kr/.

35) http://www.raemian.co.kr/.

36) http://www.xi.co.kr/. 